
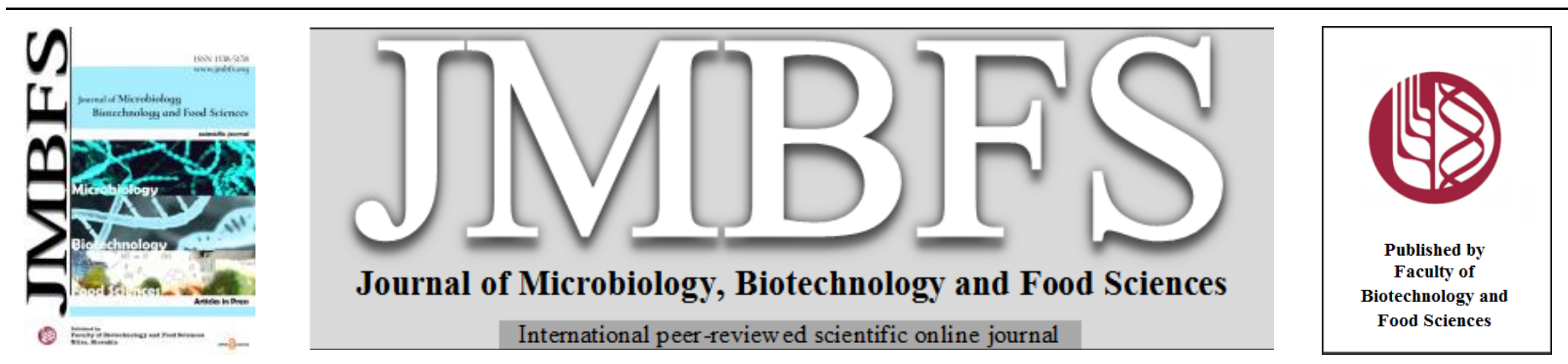

\title{
PREVENTIVE EFFECTS OF CITRULLUS COLOCYNTHIS. L PLANT EXTRACT ON DELTAMETHRIN PESTICIDE INDUCED PNEUMOTOXICITY IN WISTER RATS
}

\author{
Salim Gasmi ${ }^{1 *}$, Brahim Benaicha ${ }^{1}$, Mohamed Kebieche ${ }^{2}$, Imad Mennai $^{3}$ \\ Address(es): Dr. Salim Gasmi, \\ ${ }^{1}$ Faculty of Exact Sciences and Nature and Life Sciences, Larbi Tebessi University, Tebessa, 12002, Algeria. \\ ${ }^{2}$ Faculty of natural and life sciences, University of Batna 2, 05078, Batna, Algeria. \\ ${ }^{3}$ University of Mentouri Brothers, Constantine, 25000, Algeria
}

*Corresponding author: Salim.gasmi@univ-tebessa.dz

\section{ARTICLE INFO}

Received 9. 9. 2021

Revised 8. 12. 2021

Accepted 22. 12. 2021

Published 1. 4. 2022

Regular article OPEN $\partial_{\text {ACCESS }}$

\begin{abstract}
Pesticides are chemicals used to fight agricultural pests. Their use causes extensive damage to both humans and animals, resulting in diseases mainly affecting the respiratory and digestive systems. Through this study, we evaluated the pneumotoxicity caused by a deltamethrin (DM) insecticide at a dose of 0.64mg.kg-1.day-1. We also evaluated the preventive and curative effect of the medicinal plant "citrullus colocynthis. L" antagonist of this toxicity at a dose of $150 \mathrm{mg} . \mathrm{kg}-1$.day-1. We carried out the experimental application on Wister rats as an animal model of exhalation. Several experiments were carried out on the activity of enzymes and vital indicators. This study revealed a decrease in the concentration of the protein accompanied by a decrease in the means of development of the body [25 \pm 0.23$]$. Then, our study showed that DM has an oxidative effect, resulting in a decrease in the level of GSH [0.05 \pm 0.00$]$ and the enzymatic activity of GPx [0.34 \pm 0.05$]$. In addition to an increase in the level of MDA [4.90 \pm 0.72$]$ and the enzymatic activity of GST [0.84 \pm 0.11$]$. In addition, the histological study carried out on a fragment of lung of rats treated with this pesticide showed changes in the histological structure of the lungs resulting in vascular congestion, infiltration of inflammatory cells, thickening of the walls of blood vessels, as we do. Observed intra-alveolar hemorrhages and hyperplasia of the alveolar lining. On the other hand, we have confirmed the preventive effect of the citrullus colocynthis. $L$ after treatment with this pesticide, which has an anti-oxidant activity, which can reduce the intensity of the oxidative stress resulting from deltamethrin and its effectiveness. In the treatment of lung, tissue effected by this pesticide and it is stored in its natural state.
\end{abstract}

Keywords: Deltamethrin; Pneumotoxicity; Pyrethroids; Citrullus Colocynthis. L; Oxidative stress

\section{INTRODUCTION}

Man is one of the living beings making up the multitude of organisms in the biosphere. It remains permanently exposed to numerous attacks of various kinds, in particular toxic substances in its environment such as pesticides. The latter are the most dangerous pollutants in the environment because of their mobility and their ability to accumulate in the environment and their resulting harmful longterm effects on living organisms in general and human health in particular (Marek et al., 2013).

Their widespread use in agriculture, public health, commerce and households around the world is an indication of the importance of these compounds (Alavanja et al., 2004). In addition to their primary purpose, pesticides can also affect humans and animals in the vicinity of the insecticide sprayed area (Gasmi $\boldsymbol{e t}$ al., 2017). They are designed to interfere with living species and are necessarily characterized by varying levels of toxicity (Corsini $\boldsymbol{e t}$ al., 2007). In fact, the severity of intoxication depends on the toxicity of the product in question, the mode of penetration, the dose absorbed, the physiology and the age of the subject (MiguelBouzas et al., 2012).

The use of toxic substances with insecticidal power is very old. 2000 years ago, the Chinese were already using the powder of dried flowers, the pyrethrums (Kumar et al., 2017). In 1690, La Quintinie discovered the antiparasitic qualities of tobacco (Al-Khaldi et al., 2018). Then at the end of the 18th century and the beginning of the 19th century, arsenicals, fluorides and sulfur were in turn used. It was then, with the development of organic chemistry, that synthetic insecticides were developed, the best-known example being that of the discovery of DDT. From that moment on, many other insecticidal compounds have been discovered which are grouped together in the categories of organochlorines, organophosphorus compounds, carbamates, etc (Miguel-Bouzas et al., 2012).

Kumar et al. (2017) note that in recent years, the appearance of strains resistant to these products, in particular to organo-phosphorus compounds, as well as the increasingly in-depth knowledge of the toxic action of the natural constituents of pyrethrums will then determine the development of the large family of synthetic pyrethroids. One of these pyrethroids is deltamethrin (DM), a non-systemic insecticide belonging to the family of synthetic pyrethroids which acts rapidly by contact and ingestion (Fetoui et al., 2010). This molecule is considered an esterase inhibitor, as well as an inhibitor of the sodium channel in the membranes of neurons in insects. The active dose of deltamethrin (DM) in agricultural treatment is only 5 to $15 \mathrm{~g} / \mathrm{ha}-1$ (Gasmi, 2020). DM is considered the most toxic of the other pyrethroids because it is neither completely degraded nor rapidly metabolized and therefore accumulates in lipids (Gasmi et al., 2017).

The general objective of this work is to evaluate the pneumotoxicity of DM and the corrective effect of the extract of the $C$. Colocynthis. $L$ medicinal plant.

\section{MATERIAL AND METHODS}

Plant material

Citrillus colocynthis. L, Schrad, Handhal, حنظ or colocynth is a perennial plant belonging to the Cucurbitaceae family; $C$. Colocynthis has a rich history as a medicinal plant and as a source of valuable oil. The different parts of this species are used in traditional medicine according to their method of preparation (decoction, spraying, maceration of the seeds), against hemorrhoids in local application of the pulverized seeds, jaundice, ascites, rheumatism, amenorrhea, and gastrointestinal disorders (dysentery, constipation). Several ethnobotanical and pharmacological studies have reported the use of this herb for the treatment of diabetes (Hameed et al., 2020).

\section{Chemical material}

In this work, we used on the one hand the pesticides of DM for the treatment of rats in solution form at a dose of $0.64 \mathrm{mg} . \mathrm{kg}-1$. day-1, and on the other hand, the plant extract Citrullus colocynthis. $L$ in aqueous solution. At a dose of $150 \mathrm{mg} . \mathrm{kg}$ 1.day-1 for 30 days. Deltamethrin $\left[\mathrm{C}_{22} \mathrm{H}_{19} \mathrm{Br}_{2} \mathrm{NO}_{3}\right]$ the active ingredient in Décis ${ }^{\circledR}$ is an insecticide from the pyrethroid family which acts mainly on the sodium channels of nerve fibers which it blocks in the open position (Gasmi et al., 2017; Haddadi \& Shirani, 2014). 


\section{Laboratory animals}

The present study was carried out on male Rattus rattus rats of the Wistar strain of 32 rats, from the Pasteur Institute in Algiers, aged 06 to 08 weeks, weighing approximately $150-290 \mathrm{~g}$. They are mammals of the rodent order. Widely used in various fields of experimental research. Animal care. The rats were divided into 04 groups at the rate of 08 rats per group. They were subjected to a 30 days adaptation period in the animal facility of the Department of Biology, Faculty of Sciences, Larbi Tebessi University. The ambient temperature is $23 \pm 2^{\circ} \mathrm{C}$ and a natural $12 / 12 \mathrm{~h}$ photoperiod with a humidity of $60 \%$. The rats are reared in polyethylene cages which are lined with litter made from wood chips. The cages are cleaned and the litter is changed once every two days until the end of the experiment. The animals were fed a concentrate of bread and corn.

\section{Distribution and treatment of rats}

In this experiment, the rats are divided into 4 lots as follows:

Lots ( $\mathrm{T})$ : Contains 08 control rats received drinking water by gavage.

Lots (E): Contains 08 rats treated with Citrullus extract receiving 50mg.kg-1.day-1 for 30 days orally.

Lots (D): Contains 08 rats treated with DM at a dose of $0.64 \mathrm{mg} . \mathrm{kg}$ 1.day-1 for 30 days orally.

Lots (ED): contains 08 rats treated with the combination of DM at a dose of $0.64 \mathrm{mg} . \mathrm{kg}-1$.day- 1 and with the extract of Citrullus receiving dose of 150mg.kg-1.day-1 for 30 days orally.

- Evaluation of the effects of Citrullus on DM in rats

\section{Weight measurement}

The weight measurement is carried out on the rats every day on a regular basis during the rearing period, during either adaptation or treatment with the aid of electronic scales.

\section{Evaluation of oxidative stress parameters}

At the end of the 30-day citrullus and deltamethrin administration period, the animals are sacrificed; the lungs were quickly removed and rinsed in distilled water then weighed and kept in the freezer for the assays of the various parameters, and the other fixed in formalin in order to make histological sections

\section{GSH, MDA and Proteins levels}

Glutathione (GSH) concentration was measured utilizing the method described by weckberker and Cory (1988). The protein contents of various samples were determined according to the method of Bradford, 1976; using bovine serum albumin as a standard.

\section{GPx and GST activites}

Glutathione peroxidase (GPx) activity was measured by the procedure of Flohe and Gunzler (1984). The activity of Glutathione-S-transferase (GST) was measured according to the method of Habig et al (1974). The P-nitro benzyl chloride was used as substrate. The absorbance was measured at $340 \mathrm{~nm}$ at $30 \mathrm{~s}$ intervals for $3 \mathrm{~min}$.

\section{Histopathological examination}

For histopathological examination, pancreas was dissected and immediately fixed in bouin solution for $24 \mathrm{~h}$, processed by using a graded ethanol series, and then embedded in paraffin. The paraffin sections were cut into $5 \mu \mathrm{m}$ thick slices and stained with hematoxylin and eosin (H\&E) for light microscopic examination. The sections were viewed and photographed.

\section{Statistical analysis}

Statistical analysis was performed using ANOVA test and $p<0.05$ was considered the limit for the statistical significance; Data were expressed as means $\pm \mathrm{SEM}$.

\section{RESULTS}

\section{Effects of citrullus colocynthis. $L$ on deltamethrin on growth parameters}

The results of the evaluation of the growth parameters in terms of body weight, weight gain and relative weight during the 10 days of treatment of the different groups of animals with plant extract (E) and the pesticide (DM) are shown in Fig. 01. By measuring this parameter, we wanted to know the variation in the evolution of body weight in the group that is treated with E and DM.

The results of the evaluation of body weight show a very highly significant decrease $(p \leq 0.001)$ in body weight in the rats treated with DM compared to the control rats; While for the lots: E and E + DM no decrease was recorded (figure.
01-A); On the other hand, a decrease in body weight was recorded in the group treated subacute with DM compared to the control group $(\mathrm{p} \leq 0.01)$ (Fig. 1-B).

\section{Weight gain (WG)}

The results of the weight gain evaluation show a significant decrease $(p \leq-0.001)$ in weight gain in the batches treated with DM compared to the control batch. These results do not show a significant variation in the rats which are treated with $\mathrm{E}$ and E + D (Fig. 2).

\section{Relative lung weight (RLw)}

The results obtained following the evaluation of RLw show a very highly significant increase $(\mathrm{P} \leq 0.01)$ in the relative lung weight in the group treated with $\mathrm{DM}$ in comparison with the control group, on the other hand in the animals treated with plant E alone or associated with pesticides, they did not show any significant variation (fig. 3).

Effects of Citrillus on the pneumotoxicity of DM on biochemical parameters and redox status

\section{GSH}

The results represented in Fig. 04 show a very highly significant decrease ( $\mathrm{P} \leq$ 0.001 ) in the level of cytosolic GSH in the total lung respectively in the batches treated with DM when compared to the control. In addition, a very highly significant increase in the ED batch rats (Fig. 4).

\section{body weight}

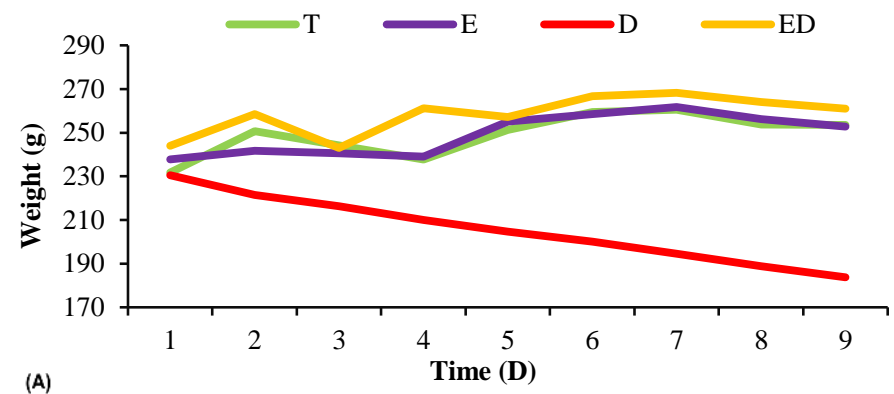

body weight In/Fn $\mathrm{n}=8$

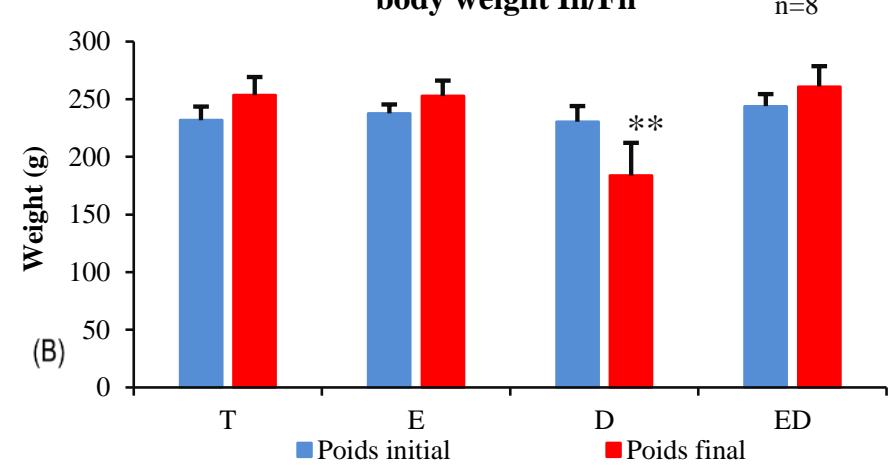

Figure 1 Evolution of body weight $(\mathrm{PC})$ in the different groups treated with pesticides and with Citrillus. (A): kinetic change in weight. (B): Difference between initial and final weight. T: Control; E: Extract of Citrillus; D: Deltamethrin; ED: Mixture Extract of Citrillus colocynthis and Deltamethrine; P: level of significance; * Significant difference: $p \leq 0.05$; ** Highly significant difference: $p \leq 0.01 ; * * *$ Very highly significant difference: $p \leq 0.001$. 


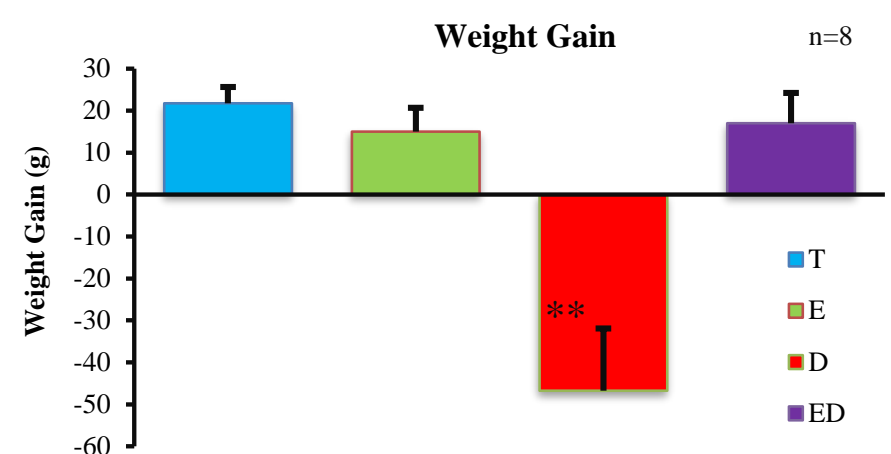

Figure 02 Evolution of body weight gain (GP) in control and treated rats after 30 days of treatment with pesticides and Citrillus. L. T: Control; E: Extract of Citrillus; D: Deltamethrin; ED: Mixture Extract of Citrillus colocynthis and Deltamethrine; P: level of significance; * Significant difference: $p \leq 0.05 ; * *$ Highly significant difference: $p \leq 0.01 ; * * *$ Very highly significant difference: $p \leq 0.001$.

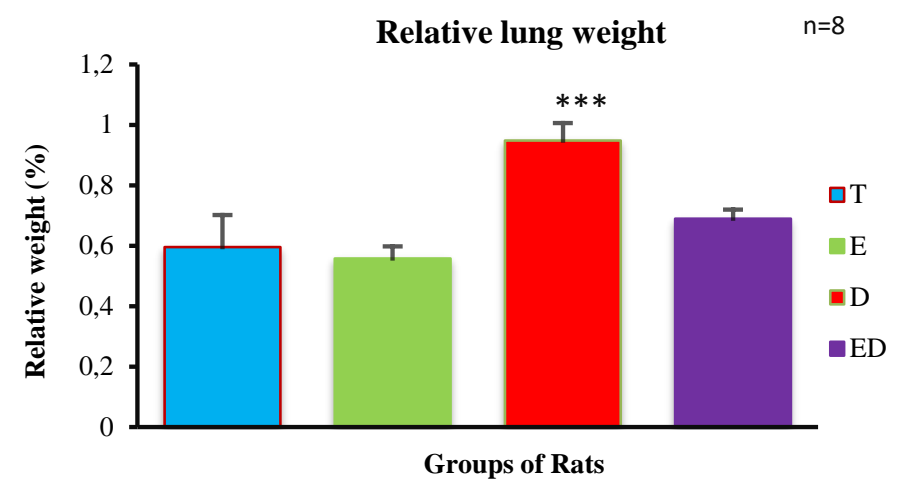

Figure 3 Evolution of the relative lung weight (RLw) in rats treated for 30 days with pesticides and Citrillus colocynthis. L. T: Control; E: Extract of Citrillus colocynthis; D: Deltamethrin; ED: Mixture Extract of Citrillus colocynthis and Deltamethrine; P: level of significance; * Significant difference: $p \leq 0.05$; ** Highly significant difference: $p \leq 0.01 ; * * *$ Very highly significant difference: $p \leq 0.001$.

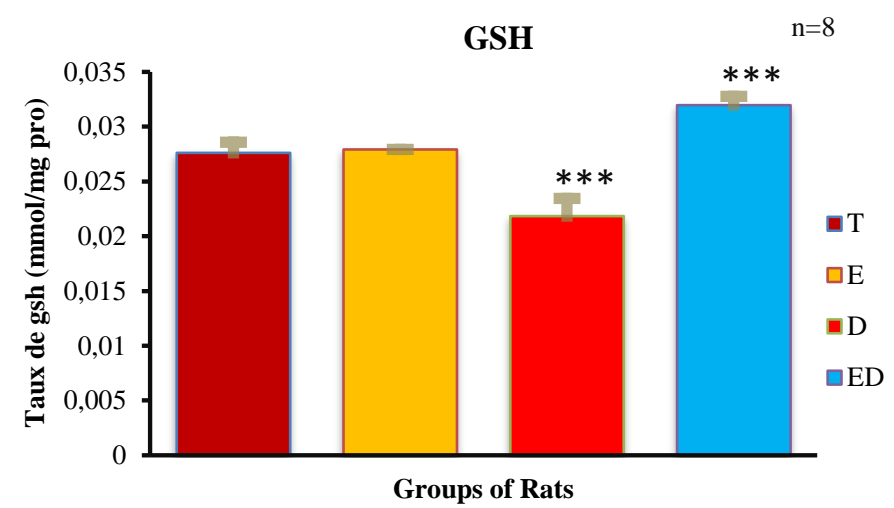

Figure 4 Change in the level of GSH in the lungs of rats after 30 days of treatment with the pesticide and the plant extract. T: Control; E: Extract of Citrillus colocynthis, D: Deltamethrin; ED: Mixture Extract of Citrillus colocynthis and Deltamethrine; P: level of significance; * Significant difference: $p \leq 0.05 ; * *$ Highly significant difference: $p \leq 0.01 ; * * *$ Very highly significant difference: $p \leq 0.001$.

\section{GST}

Statistical analysis of the results obtained after the evaluation of the cytosolic activity of GST showed a significant increase ( $\mathrm{p} \geq 0.05)$, in the level of total GST in the DM groups compared to the control group; the results do not show a significant variation in lots $\mathrm{E}$ and $\mathrm{E}+\mathrm{D}$ (Fig. 5).

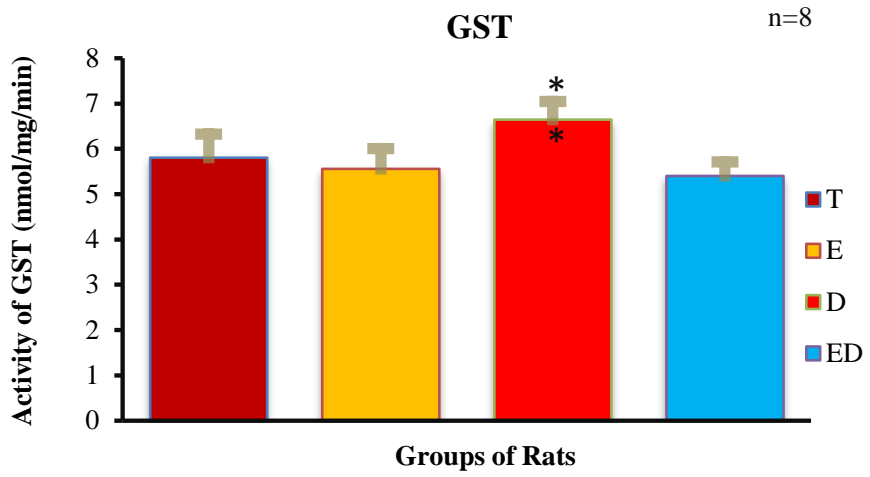

Figure 5 Change in the level of GST in the lungs of rats after 30 days of treatment with the pesticide and the plant extract. T: Control; E: Extract of Citrillus colocynthis, D: Deltamethrin; ED: Mixture Extract of Citrillus colocynthis and Deltamethrine; P: level of significance; * Significant difference: $p \leq 0.05$;** Highly significant difference: $p \leq 0.01$; *** Very highly significant difference: $p \leq 0.001$.

GPx

A significant decrease $(\mathrm{p} \leq 0.05)$ in cytosolic GPx activity was recorded in the cytosol of lung cells in DM-treated rats compared to the control group. On the other hand, these same results do not show a statistically significant variation in the groups treated with $\mathrm{E}$ and $\mathrm{E}+\mathrm{D}$ (Fig. 6).

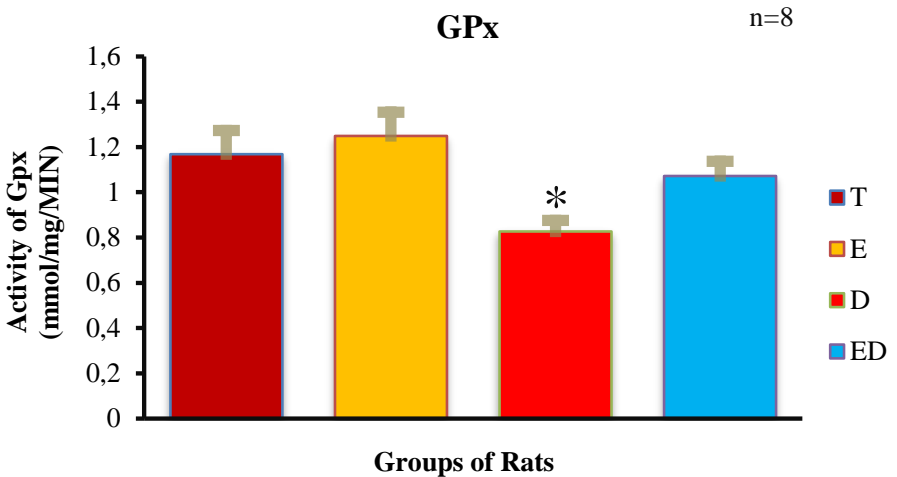

Figure 6 Change in the level of GPx in the lungs of rats after 30 days of treatment with the pesticide and the plant extract. T: Control; E: Extract of Citrillus colocynthis; D: Deltamethrin; ED: Mixture Extract of Citrillus colocynthis and Deltamethrine; P: level of significance; * Significant difference: $p \leq 0.05 ;{ }^{* *}$ Highly significant difference: $p \leq 0.01 ; * * *$ Very highly significant difference: $p \leq 0.001$.

\section{MDA}

Fig. 7 illustrates a very highly significant increase $(\mathrm{p} \leq 0.001)$ in the groups treated with DM and a significant increase $(\mathrm{p} \leq 0.05)$ in the group treated with the ED mixture compared to the control; These results do not show statistically significant variations in the groups treated with the plant (E).

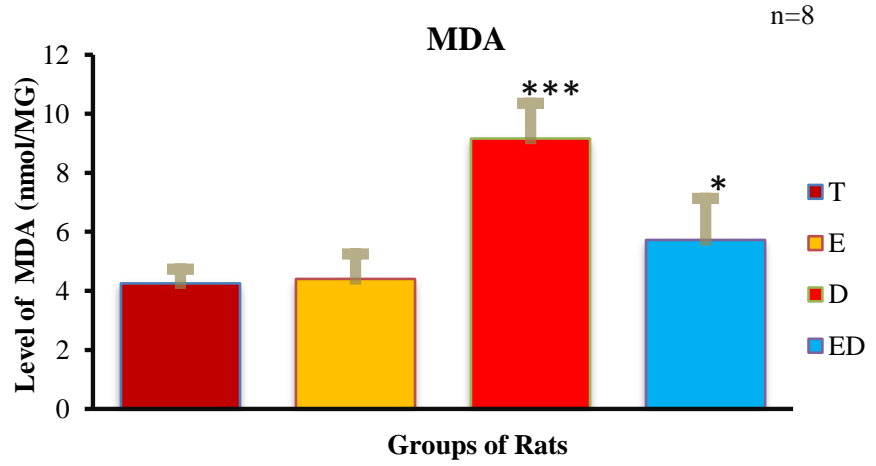

Figure 7 Change in the level of MDA in the lungs after 30 days of treatment with the pesticide and the extract. T: Control; E: Extract of Citrillus colocynthis; D: Deltamethrin; ED: Mixture Extract of Citrillus colocynthis and Deltamethrine; P: level of significance; * Significant difference: $p \leq 0.05 ; * *$ Highly significant difference: $p \leq 0.01 ; * * *$ Very highly significant difference: $p \leq 0.001$.

\section{Proteins}

The results obtained show a significant decrease $(p \leq 0.05)$ in the total protein level of the lung in the DM batches compared to the control and a highly significant 
increase $(\mathrm{p} \leq 0.01)$ is observed in the batches treated with the ED mixture compared to the batches. Control; but the latter do not show a significant variation in the groups treated with extract E (Fig. 8).

\section{Effects of Citrullus colocynthis on Deltamethrin-Induced Pneumotoxicity in Lung Tissues}

To confirm the results of biochemical parameters of oxidative stress we performed a histological testing procedure on the lungs of different groups of experimental animals (Fig. 9)

Controls $(\boldsymbol{T})$ : The results obtained show that the pulmonary parenchyma has alveoli of normal morphology and branches with vascular structure (fig. 9-A).

Extract $(\boldsymbol{E})$ : This figure shows that the pulmonary parenchyma is made up of alveoli and branches with the presence of vascular structure; there is a discreet dilation of the branches with conjunction of the alveoli and signs of vascular conjunction and mini inflammatory lymphocytic infiltration were found; in comparison to the control (fig. 9-B).

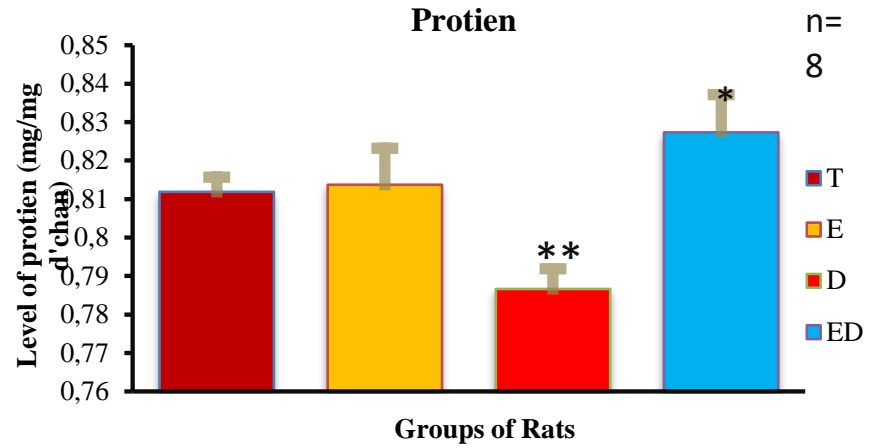

Figure 8 Variation of the Protein level in the lungs of rats after 30 days of treatment with the pesticide and the plant extract. T: Control; E: Extract of Citrillus colocynthis; D: Deltamethrin; ED: Mixture Extract of Citrillus colocynthis and Deltamethrine; P: level of significance; * Significant difference: $p \leq 0.05 ; * *$ Highly significant difference: $p \leq 0.01 ; * * *$ Very highly significant difference: $p \leq 0.001$.

Deltamethrin $(\boldsymbol{D})$ : the results show that the pulmonary parenchyma is made up of alveoli and branches with the presence of vascular structure; there is a presence of hemorrhage alveolitis (inflammatory cells) whose alveoli are edematous and pruned by hemorrhage and also inflammatory lymphocytic infiltration of low to moderate intensity harsh in places denounces mononuclear grouped in aggregate and presence of vascular conjunction by report to the Control (Figure 09-C).
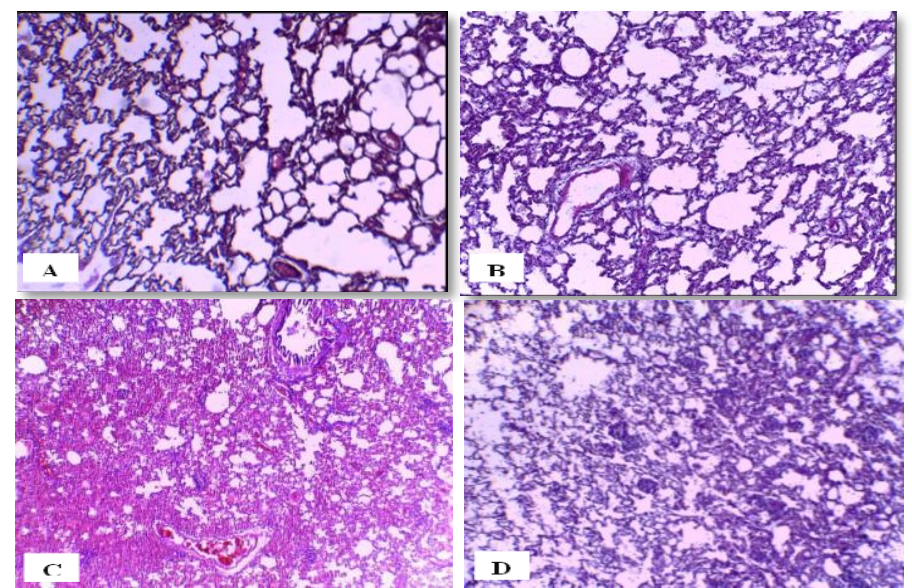

Figure 9 Histological sections $(\times 40)$ in the striatum of control rats treated with citrillus colocynthis (E), deltamethrin (D), and their combinations after 30 days of treatment. Histological sections $(\times 40)$ in the striatum of mice treated with citrus colosynthes (E), deltamethrin (D), and their combinations after 30 days of treatment. The arrows show the areas affected by tissue or cellular damage, as this damage could be the result of an apoptosis (organized) or sudden cellular death of the cells of these tissues.

Pesticide Mixture and Extract (ED): Figure 09-D show that the pulmonary parenchyma makes alveoli and branches with the presence of vascular structure; there is a slight haemorrhage and vascular conjunction; in comparison with the control group (Figure 09-D).

\section{DISCUSSION}

Oxidative stress is not a disease, but it creates or accelerates the conditions for the disease. Diagnosis and monitoring are therefore of fundamental importance in the context of preventive medicine, health, monitoring of treatments and pathologies (Bobali, 1991). The involvement of oxidative stress in the development of many pathologies and in the aging process is widely documented in the scientific literature. A certain craze has led to believe that antioxidants could be the solution to treat and prevent the most serious diseases, and to age well. The empirical intake of certain antioxidants over the long term appears increasingly questionable. Hence the growing interest in the search for markers of oxidative stress (Gasmi, 2020).

This study treated the toxic effects of deltamethrin on the pulmonary system dear to rats after exposure to a dose of $0.64 \mathrm{mg} . \mathrm{kg}-1$.day-1, as well as the protective effect of citrullus colocynthis against the toxicity of this pesticide were put in view evidence by investigation of metabolic parameters, enzymatic parameters, non enzymatic parameters and growth parameters. In this study allowed us to illustrate the relationship between exposure to this pesticide deltamethrin and the toxic effects they induce, and the preventive and curative effect of an extract of a medicinal plant.

\section{Effects of deltamethrin and citrullus colocynthis on growth parameters}

Monitoring of body mass in mice treated with the pesticide deltamethrin (DM) and Plant Extract citrullus colocynthis $L$ shows a decrease in body weight and weight gain in the batches treated with Deltamethrin compared to the control batches Agrees with several studies where the same effect has been noted in laboratory animals (Emara and Draz, 2007; Zhang et al., 2008). The reduction in the rate of body weight gain is used as an indicator of toxicity and deterioration in the general health of rats. This decrease may be due to the effect of pesticides on the gastrointestinal tract through loss of appetite and / or poor food absorption thus causing a reduction in food and water consumption in treated rats by the pesticide (Mairif, 2015). The decrease in body weight gain may also be the result of the disruption of cell metabolism under the effect of the oxidative stress generated by ROS observed in this study, as well as by other chemical mediators such as certain pro-inflammatory cytokines. The organism can release after the toxic effects of pesticides (Carole and Harve, 2011; Viviana, 2015). Regarding the effect on the relative weight of the lung, we noticed a very highly significant increase. This can be explained, on the one hand, by the tissue hypertrophy of this organ caused by deltamethrin and on the other hand by the intense accumulation of the pesticide itself in this target organ (Kehili, 2017) obtained the same results by studying the toxicity of cadmium on several organs. In addition, the capacity of the extract of citrullus colocynthis to preserve these weight parameters of the animals. This could be the consequence of its antioxidant power (This plant contains many antioxidants) according to research of Hameed et al., (2020).

\section{Effects of deltamethrin and citrullus colocynthis on redox status}

\section{GSH}

Reduced Glutathione (GSH) is a tri peptide (Glu-Cys-Gly) contains a nucleophilic thiol group that readily reacts with alkaline xenobiotics (Tremblay, 2018). It plays a role in detoxifying endogenous or xenobiotic substances and protects cells against oxidative stress. Our results show a decrease in the level of pulmonary GSH after exposure to deltamethrin. This decrease is a response to oxidative stress caused by deltamethrin (Kumar et al., 2017). Reduced glutathione (GSH), reduces hydrogen peroxide and/or organic peroxides thanks to the reaction catalyzed by glutathione peroxidase (GPx) (Garait, 2006). The decrease in GSH levels indicates that the rat body is building the antioxidant defense system (Grara et al., 2012; Kehili et al., 2017).

\section{GST}

GST is an enzyme with an important role in the detoxification of xenobiotics and the protection against harmful metabolites generated after the degradation of macromolecules (Aouacheri et al., 2009). According to our results, we observe a highly significant increase in GST in the tissues studied (lung) in the DM batch compared to the other treatment batches, Our results are consistent with the study (Kehili et al., 2017). The increase in the activity of this enzyme is a physiological response to compensate for the damage that is due to free radicals (Rouabhi et al., 2015)

\section{GPx}

GPx is one of the very powerful antioxidant defense systems; it reduces $\mathrm{H}_{2} \mathrm{O}_{2}$ to $\mathrm{H}_{2} \mathrm{O}$ and protects the body against the cancerous effect of this substance (Zhu et al., 2010). The results obtained revealed that the rats treated with deltamethrin underwent a significant decrease in GPx activity, these results in agreement with the work of (Gasmi et al., 2017). The observed decrease in GPx activity in lung tissue following treatment with deltamethrin could be due to their indirect action in reducing the levels of reactive oxygen species, which may reduce oxidative stress work on toxicity caused by a xenobiotic (Kehili et al., 2017). 
MDA

The DM toxicity studied was a very highly significant cause of MDA levels, which is the main active aldehyde in the peroxidation of polyunsaturated fatty acid in membranes according to this study (Maiza et al., 2011). ROS can oxidize lipids (Ercal et al., 2001). Lipid peroxidation is followed by the disintegration of biological cell membranes (Fetoui et al, 2009; Bebianno et al., 2005) or other elements containing lipids (Al-mutairi, 2007). This results in a loss of membrane permeability and potential, inactivation of receptors and membrane enzymes (Pampanin, 2005). These functional disturbances can lead to cell death. Thus, lipid peroxidation is an endogenous source of DNA damage (Marnett, 2002). On the other hand, studies by (Harris, 1992) show an overproduction of MDA in earthworms treated with zinc oxide and titanium oxide $(0.1,0.5,1$ and $5 \mu \mathrm{g} / \mathrm{g})$. For the majority of the parameters studied a supply of citrullus colocynthis. $L$ bark extract in the rats treated with the studied pesticide improved the Redox status of the animals by restoring a certain balance of primary metabolites (MDA) but also of enzymatic biomarkers (GPx , GST) and non-enzymatic explored (GSH). This can be explained by the richness of citrullus colocynthis in polyphenols (Gasmi et al., 2017), molecules endowed with an immense antioxidant power (Macheix et al., 2005), mainly due to the presence of hydroxyl functions on the benzene nucleus of these phenolic compounds. Polyphenols, which are molecules of exclusively plant origin, are the basis for the design of most drug preparations, due to their various biological activities (Macheix et al., 2005). In this study, they demonstrated a strong therapeutic power against poisoning with the phytosanitary product, namely deltamethrin.

\section{Protein}

The results of this study show a highly significant decrease in metabolic parameters in rats treated with DM compared to the control batch (Gasmi et al., 2017). The decreased protein level is explained here by protein denaturation but also by the decrease in protein synthesis due to damage to the transcription-translation system at the cellular level. Another explanation would be the excessive use of protein molecules involved in the antioxidant defense against ROS released following the consumption of different xenobiotics (Najib et al., 2010). Oxidized proteins are generally destroyed by cells as a defense mechanism. This mechanism is orchestrated by proteasomes and some proteases of lysosymes (Bobali, 1991). On the other hand, according to the results obtained and what we observed in the batch treated with a mixture (pesticide and the plant) during the use of citrullus colocynthis as a cytoprotective molecule, it turns out that this phenolic compound has greatly improved 1 homeostasis of biochemical parameter studied in this present work (proteins) (Leclerc, 2012). This preventive power could be attributed to the antioxidant molecular characteristics of this polyphenol through the cathechol group, the unsaturated bonds of the $\mathrm{C}$ nucleus, the 4-oxo function and the groups with chelating affinity of the metals which characterize this compound These results are in agreement with numerous studies on this polyphenol (Lahouel et al., 2016; Lee et al., 2016).

\section{Treatment effects on the histology of lung tissue}

Exposure to pesticides can cause adverse effects on health and on various organs and tissues, including the respiratory tract and the lungs. The results revealed alterations in the histological structure of the lungs characterized by vascular congestion, inflammatory cell infiltrates, thickening of the vascular walls, intraalveolar hemorrhages and hyperplasia of the alveolar lining which leads to a reduction in the lumen of the alveoli. The results are similar to the results of this study (Mairif, 2015). These alterations are accompanied by an increase in the relative weight of the lungs. It was observed that treatment with oral deltamethrin caused histological changes in the lungs in the treated rats. Where we notice a decrease in alveolar diameter, an inflammation evidenced by the presence of inflammatory cells with cell necrosis, the results are similar to the results of this study (Mestaghanmi et al., 2014). In addition, a study showed that exposure to HCB induced pulmonary inflammatory lesions with accumulations of alveolar macrophages and proliferation of the pulmonary vessel endothelium, which was Controled by perivascular infiltrate, composed of eosinophilic granulocytes and monocytes (Michielsen et al., 1997; Michielsen et al., 1999). In addition, an increase in lung weight was observed in rats and guinea pigs exposed by inhalation to $6.1 \mathrm{mg} . \mathrm{Al} / \mathrm{m} 3$ (as aluminum hydrochloride) at a rate of $6 \mathrm{~h} / \mathrm{day}, 5 \mathrm{~d} /$ week for 2 years (Stone et al., 1979). Also, this study confirm the research of Grassina et al., (2011), about the use of cannabis bong results in pulmonary intoxication and alveolar hemorrhage. In this same study, it was also found that citrullus colocynthis. L played an important role in the protection of lung tissue, as well as contributing to the remodeling of tissue damaged by inflammation and alveolar hemorrhage caused by the deltamethrin pesticide.

\section{CONCLUSION}

The administration of citrullus colocynthis. $\mathrm{L}$ at a dose of $150 \mathrm{mg} / \mathrm{kg} / \mathrm{day}$ for 30 days to rats treated with deltamethrin at a dose of $0.64 \mathrm{mg} / \mathrm{kg} /$ day restored all values to normal, which reflects the protective effect of citrullus colocynthis. $L$ on lung function.

Funding: This work was done without a specific grant from any funding agency

Conflicts of interest/competing interests: The authors declare that they have no conflict of interest.

Ethics approval: All of the experimental protocols were approved and performed by the ethics committee of Pasteur Institute of Algeria (PIA) under the ethical code: No.2503/3.2016.

\section{REFERENCES}

Alavanja, M. C., Hoppin, J. A., Kamel, F. (2004). Health effects of chronic pesticide exposure: cancer and neurotoxicity. Annuel.Revue.Public.Health. 25:155-197. https://doi.org/10.1289/ehp.113-1314952

Al-Khaldi, M., \& Taha, A. (2008). Study of the Dissociation Constants of Some Weak Indicator Bases in Ethyl Cellosolve - Water Solvent Mixtures. Journal of King Abdulaziz University-Science, 20(1), 111-122. https://doi.org/10.4197/sci.20-1.9

Al-Mutairi D., Craik J., Batinic H., Benov L. 2007. Induction of oxidative cell damage by photo - treatment with zincs Meta N-methylpyridylporphyrin. Free radical research. 41: 89-96. https://doi.org/10.1146/annurev.publhealth.25.101802.123020

Aouacheri, W., Saka, S., Djafer, R., Lefranc, G. (2009). Effet protecteur du diclofénac contre le stress oxydatif induit per la toxicité du paracétamol chez le rat. Ann Biol Clin. 67 (6): 619-27. 621. https://doi.org/10.1289/ehp.113-1314952 Aouey, B., Derbali, M., Chtourou, Y., Bouchard, M., Khabir, A., \& Fetoui, H. (2017). Pyrethroid insecticide lambda-cyhalothrin and its metabolites induce liver injury through the activation of oxidative stress and proinflammatory gene expression in rats following acute and subchronic exposure. Environmental Science and Pollution Research, 24(6), 5841-5856. https://doi.org/10.1007/s11356-016-8323-4

Bakadia, B. M., Boni, B., Ahmed, A., \& Yang, G. (2021). The impact of oxidative stress damage induced by the environmental stressors on COVID-19. Life sciences, 264, 11865. https://doi.org/10.1016/j.lfs.2020.118653

Beutler, E., Duron, O., Kelly, B. M. (1963). Improved method for the determination of blood glutathione. J Lab Clin Med. 61:882-890 https://doi.org/13967893

Bossou, Y. M., Côté, J., Mantha, M., Haddad, S., Achard, S., \& Bouchard, M. (2020). Impact of pesticide coexposure: an experimental study with binary mixtures of lambda-cyhalothrin (LCT) and captan and its impact on the toxicokinetics of LCT biomarkers of exposure. Archives of Toxicology. https://doi.org/10.1007/s00204-020-02810-6.

Bourhia, M., Bouothmany, K., Bakrim, H., Hadrach, S., Salamatullah, A. M., Alzahrani, A., Khalil Alyahya, H., Albadr, N. A., Gmouh, S., Laglaoui, A., El Mzibri, M., Benbacer, L. (2021). Chemical Profiling, Antioxidant, Antiproliferative, and Antibacterial Potentials of Chemically Characterized Extract $\begin{array}{llllll}\text { of Citrullus colocynthis. L. Seeds. Separations, } & 8, & 114\end{array}$ https://doi.org/10.3390/separations8080114

Bradford, M. (1976). A rapid and sensitive method for the quantitation of microgram quantities of protein utilizing the principle of protein-dye binding Analytical Biochemistry, 72(1-2), 248-254 https://doi.org/10.1006/abio.1976.9999

Carole, I. \& Harvé, Q. (2011). Désordres métaboliques et réanimation : de la physiopathologie au traitement. Berlin Heidelbeng. New York. ISBN: 978-2-28799026-7. 522p.

Corsini, E., Codecà, I., Mangiaratti, S., Birindelli, S., Minoia, C., Turci, R. (2007) Immunomodulatory effects of the herbicide propanil on cytokine production in humans: In vivo and in vitro exposure. Toxicol.Appl.Pharmacol. 222: 202-210p. https://doi.org/10.1016/j.taap.2007.04.017

Emara, A., Draz, E. (2007). Immunotoxicological study of one of the most common overthe-counter pyrethroid insecticide products in Egypt. Inhalation Toxicology. 19(12): 997-1009. https://doi.org/10.1080/08958370701533483

Ercal, N., Gurer-Orhan, H., Aykin-Burns, N. (2001). Toxic metals and oxidative stress part I: mechanisms involved in metal-induced oxidative damage. Current topics in medicinal chemistry. 1 : 529-39. https://doi.org/10.2174/1568026013394831

Fetoui, H., Makni, M., Garoui, M., Zeghal, N. (2010). Toxic effects of lambda cyhalothrin, a synthetic pyrethroid pesticide, on the rat kidney: Involvement of oxidative stress and protective role of ascorbic acid. Experimental and toxicologic pathology. 593-599.

Flohe, G. (1984). Analysis of glutathione peroxidase. Methods Enzymol. 105:114 121. https://doi.org/10.1016/j.etp.2009.08.004

Fouzai, C., Trabelsi, W., Bejaoui, S., Telahigue, K., Rabeh, I., Nechi, S., Chelbi, E., El Cafsi, M., \& Soudani, N. (2020). Cellular toxicity mechanisms of lambdacyhalothrin in Venus verrucosa as revealed by fatty acid composition, redox status and histopathological changes. Ecological Indicators. 108, 105-690. https://doi.org/10.1016/j.ecolind.2019.105690 
Garait, B. (2006). Le stress oxydant induit par voie métabolique (régimes alimentaires) ou par voie gazeuse (hyperoxie). Thèse Doctorat. Université Joseph Fourier. Grenoble. $\quad$ France. 4-99p. https://doi.org/10.1016/j.freeradbiomed.2005.06.026

Gasmi, S. (2020). Neurotransmission dysfunction by mixture of pesticides and preventive effects of quercetin on brain, hippocampus and striatum in rats. Toxicol. Environ. Health Sci. 12, 203-212. https://doi.org/10.1007/s13530-020-00012-2

Gasmi, S., Chafaa, S., Lakroun, Z. et al. (2019). Neuronal Apoptosis and Imbalance of Neurotransmitters Induced by Acetamiprid in Rats. Toxicol. Environ. Health Sci. 11, 305-311. https://doi.org/10.1007/s13530-019-0417-1

Gasmi, S., Rouabhi, R., Kebieche, M., Boussekine, S., Salmi, A., Toualbia, N., Taib, C., Bouteraa, Z., Chenikher, H., Henine, S., Djabri, B. (2017). Effects of Deltamethrin on striatum and hippocampus mitochondrial integrity and the protective role of Quercetin in rats. ESPR. 24(19):16440-16457. https://doi.org/10.1007/s11356-017-9218-8

Grara, N., Boucenna, M., Atailia, A., Berrebbah, H., Djebar, M.R. (2012). Stress oxydatif des poussi_eres $m$ etalliques du complexe sid erurgique d'Annaba (Nord-Est alg_erien) chez l'escargot Helix aspersa. Environ Risque Sante. 226. https://doi.org/10.1684/ers.2012.0534

Haddadi, H., Shirani, M., Semnani, A. (2014). Simultaneous Determination of Deltamethrin and Permethrin in Water Samples Using Homogeneous LiquidLiquid Microextraction via Flotation Assistance and GC-FID. Chromatographia. 77, 715-721. https://doi.org/10.1007/s10337-014-2666-0

Hameed, B., Ali, Q., Hafeez, M., \& Malik, A. (2020). Antibacterial and antifungal activity of fruit, seed and root extracts of citrullus colocynthis plant. Biological and Clinical Sciences Research Journal, (1)-033. https://doi.org/

Kehili, N., Saka, S., Aouacheri, O. (2017). L'effet phytoprotecteur de la nigelle (Nigella sativa) contre la toxicité induite par le cadmium chez les rats. Phytotherapie. 6 -7-8.

Kumar, A., Sasmal, D. \& Sharma, N. (2017). Mechanism of deltamethrin induced thymic and splenic toxicity in mice and its protection by piperine and curcumin: in vivo study. Drug and Chemical Toxicology http://doi.org/10.1080/01480545.2017.1286352

Leclerc, P. L. (2012). Elaboration de nanoparticules de protéines de lactosérum comme système d'administration de quercétine en système gastro-intestinal. Thèse doctorat en Sciences et technologie des aliments (Ph.D.) Université Laval Québec. 12-44, 57-110. https://doi.org/

Lee, J., Koo, N., Min, D. B. (2004). Reactive Oxygen Species, Aging, and Antioxidative Nutraceuticals. Food Science and Food Safety. 3: 21-33. https://doi.org/10.1111/j.1541-4337.2004.tb00058.x

Macheix, J. J., Fleuriet, A., Jay-allemand, C. (2005). Les composes phenoliques des végétaux : un exemple de matabolites secondaires d'importance economique, première edition, presses polytechniques et universitaires romandes, lausanne bio ed. 54-65. https://doi.org/ISBN:2-88074-625-6

Mairif, S. (2015). Contribution à l'étude de l'effet toxique des pesticides à usage domestique utilisé en Algérie. Thése Doctorat. Université GUELMA. 82-95p.

Maiza, A., Kilani-morakchi, S., Rehamnia, F., Bensbaa, F., ARIBI, N. (2011). Activité d'un biopesticide, le spinosad, chez blattella germanica: effets sur divers biomarqueurs. (ldh, gsh, mda). 199-200p. https://doi.org/10.1018/4767638-8734 Mannervik, B. (2006). The Isoenzymes of Glutathione Transferase. In Advances in enzymology and related areas of molecular biology. 357-417. https://doi.org/10.1016/0041-008x(79)96578

Mestaghanmi, H., Elamrani, S., M'touguy, I., Saile, R. (2014). Le placenta murin : barrière efficace contre différents toxiques, dont l'aluminium .Effets du chlorure d'aluminium sur la structure histologique des poumons, reins et intestin des rats femelles gestantes et leurs foetus. La Gazette du laboratoire; 82 : 4-5. https://doi.org/10.1015/0076348-8787-2

Miguel-Bouzas, J. C., Castro-Tubio, E., Bermejo-Barrera, A.M., FernandezGomez, P., Estevez-Nunez, J. C., Tabernero-Duque, M. J. (2012). Epidemiological study of acute poisoning cases treated at a Galician hospitalbetween 2005 and 2008. Adicciones. 24(3) :239-46. https://doi.org/

Sharifi-Rad, M., Anil Kumar, N.V., Zucca, P., (2020) Lifestyle, Oxidative Stress, and Antioxidants: Back and Forth in the Pathophysiology of Chronic Diseases. Front. Physiol. 11:694. https://doi.org/10.3389/fphys.2020.00694

Stone, C. J., Mc Laurin, D. A., Steinhagen, W. H., Cavender, F. L., Haseman, J. K. (1979). Tissu deposition patterms after chronic inhalation exposures of rats and guinea pigs to aluminium chlorhydrate. Toxicol.Appl.Pharmacol; 49(1) : 71-76p. https://doi.org/10.1016/0041-008x(79)90278-3

Tremblay, A. (2018). Etude in vitro de l'induction de stress oxydatif par la doxorubicine dans les cellules de sertoli immatures et les spermatogonies. Thése Doctorat. Université du Québec. 34-35p. https://doi.org/10.4000/rfsic.5830

Viviana, V.L. Angélica, T.B. Lina, G.M., Alejandro, M., Marisol, R.L. (2015) Acute restraint stress and corticosterone transiently disrupts novelty preference in an object recognition task. Behav Brain Res. 291: 60-66p https://doi.org/10.1016/j.bbr.2015.05.006

Warso, M. A., Lands, W. E. (1983). Lipid peroxidation in relation to prostacyclin and thromboxane physiology and pathophysiology. British Medical Bulletin, 39(3),277-280. https://doi.org/10.1093/oxfordjournals.bmb.a071833
Zhang, J., Zhu, W., Zheng, Y., Yang, J. \& Zhu, X. (2008). The antiandrogenic activity of pyrethroid pesticides cyfluthrin and beta-cyfluthrin. Reprod Toxicol. 25(4) :491-6. https://doi.org/10.1016/S1872-2040(17)61045-4

Zhu, Y., Chang, Y., Chen, Y.S. (2010). Toxicity and bioaccumulation of TiO2 Nanoparticle aggregates in Daphnia magna. 88-91p. https://doi.org/10.1016/j.chemosphere.2009.11.013 